This work is licensed under Creative Commons Attribution 4.0 International (CC BY 4.0). [http://creativecommons.org/licenses/by/4.0/]

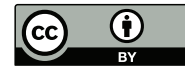

\title{
Nowoczesne technologie w dyplomacji
}

Paulina Król | Uniwersytet Gdański https://orcid.org/0000-0003-2335-6766

Słowa kluczowe: dyplomacja cyfrowa, dyplomacja technologiczna, dyplomacja cybernetyczna dyplomacja publiczna, technologie informacyjno-komunikacyjne

Keywords: digital diplomacy, tech diplomacy, cyber diplomacy, public diplomacy, information and communications technology, ICT

\section{Streszczenie}

Artykuł ma na celu przemodelowanie postrzegania dyplomacji w świecie zdominowanym przez nowe technologie. Technologia w dyplomacji funkcjonuje wielopoziomowo i widocznie wpłynęła zarówno na praktykę dyplomatyczną, sposób komunikacji, pozyskiwanie informacji, a także zmieniła i nadal zmienia zasady współpracy rządów z firmami, m.in. technologicznymi. W czasach, gdy priorytetem staje się obrona kraju w cyberprzestrzeni, konieczne jest zdementowanie opinii tyleż powszechnej, co błędnej, jakoby dyplomacja cyfrowa oznaczała jedynie korzystanie z mediów społecznościowych przez dyplomatów. Artykuł wyraźnie wskazuje nową rolę, jaką technologia odegrała w swoistej metamorfozie dyplomacji.

\section{Modern technologies in diplomacy (Summary)}

The article is aimed to reshape the perception of diplomacy in the world captured by new technologies. Technology in diplomacy exists on different levels and evidently affects diplomatic practice, the way of communication and information obtaining. It also changed and is still changing the rules of cooperation between governments and technological companies. When the cybersecurity became one of the priorities, it is essential to nail a myth that digital diplomacy means only using a social media by diplomats. It is not. The article clearly shows the new role, which technology plays in a metamorphosis of diplomacy.

\section{Wstęp}

Zagadnienie technologii w dyplomacji coraz częściej staje się przedmiotem badań i dociekań badaczy reprezentujących różne dziedziny nauki. Jednak w dalszym ciągu gros z nich koncentruje swoje analizy wokół funkcji komunikacyjnej nowoczesnych narzędzi, dostępnych za pośrednictwem Internetu, zamykając je następnie w ramy dyplomacji publicznej. Komunikowanie się dyplomatów za pośrednictwem nowych technologii faktycznie jest istotnym następstwem wpływu, który technologia wywarła na dyplomację, jednak skala problemu jest znacznie większa. W tym miejscu nasuwa się wniosek, 
który notabene stanowi myśl przewodnią rozważań, że świadomość roli, jaką technologia odgrywa w dyplomacji, nadal jest zbyt niska.

Na potrzeby niniejszego artykułu dyplomację będę definiować kompleksowo - jako instytucję, misję, międzynarodowe negocjacje, nośnik interesów narodowych poszczególnych państw (Surmacz 2015: 87), a także korpus dyplomatyczny. W każdym z wymienionych przeze mnie przypadków spełniony jest warunek międzynarodowości, która jest podstawową cechą dyplomacji. W artykule znajdą się również nawiązania do działań pozadyplomatycznych, które uznałam za interesujące w omawianym kontekście.

Technologię, która jest fundamentem pracy, rozumiem jako technologie informacyjno-komunikacyjne (ang. information and communication technologies, ICT) - tzn. wszelkie działania, które powiązane są z „produkcją i wykorzystaniem urządzeń informatycznych i telekomunikacyjnych" (Seweryn 2017: 12).

Człowiek już dawno przestał być nośnikiem informacji. Czasy, kiedy to posłańcy przekazywali wiadomości między państwami, dawno minęły. Zmiany cywilizacyjne doprowadziły do powstania społeczeństwa informacyjnego, które charakteryzuje się „przygotowaniem i zdolnością do użytkowania systemów informatycznych oraz wykorzystuje usługi telekomunikacyjne do przekazywania i zdalnego przetwarzania informacji" (Seweryn 2017: 12). Nowoczesne technologie wymusiły zmiany na każdym poziomie również na poziomie działań dyplomatycznych. Technologie informacyjne wpływają nie tylko na relacje pomiędzy aktorami międzynarodowymi, ale "prowadzą również do zmiany struktury systemu międzynarodowego" (Surmacz 2015: 126).

Warto w tym miejscu zauważyć, że w poczet aktorów międzynarodowych wstępują coraz śmielej firmy-giganty technologiczne, których rola od pewnego czasu bardzo się uwidacznia.

Artykuł podzieliłam na dwie zasadnicze części: dyplomatyczny ład w cyberprzestrzeni oraz nowe trendy w dyplomacji, w których podejmuję próbę posegregowania poszczególnych form dyplomacji celem przemodelowania postrzegania roli ICT w działaniach dyplomatycznych w ogóle.

Technologia zaczęła przenikać na salony dyplomatyczne już blisko dwie dekady temu, niosąc ze sobą zmiany w procesach informowania i komunikowania (Surmacz 2015: 125), jednak do dzisiejszego dnia kojarzona jest przede wszystkim z mediami społecznościowymi. Pogląd ten prezentuje m.in. Marcin Kosienkowski w pracy Dyplomacja cyfrowa po rosyjsku (2014). Szereg badaczy problemu wskazuje na takie odmiany dyplomacji, jak twitterowa czy facebookowa (Kosienkowski 2014: 187). Nazwa pochodzi oczywiście od medium społecznościowego, które jest narzędziem komunikacji.

Technologia w dyplomacji zaczęła przyjmować bardzo różne formy. Twitterowa i facebookowa stanowią jedynie wierzchołek problemu z terminologią. Obecnie obok digital diplomacy, cyber diplomacy, virtual diplomacy, e-diplomacy wymieniane są też tech diplomacy czy techplomacy. 
Powstanie tak bogatej nomenklatury okołotechnologicznej nierzadko bywa źródłem wielu niezręczności. Pewien ład w tej materii tworzy przyporządkowanie poszczególnym nazwom ich funkcji, dlatego też analiza jest najlepszą metodą przedstawienia poniższych zagadnień, przede wszystkim ze względu na swój systematyzujący charakter.

Dyplomację cyfrową określić można najprościej jako korzystanie przez dyplomatów z technik informatycznych, nie tylko w celu komunikacji, ale również w celu pozyskiwania informacji czy danych. Ciekawą interpretację przedstawia były brytyjski dyplomata Shaun Riordan w tekście zatytułowanym Cyber Diplomacy vs. Digital Diplomacy: A terminological distinction (2016), proponując wyraźne rozdzielenie dwóch wyżej wskazanych pojęć (cyber diplomacy oraz digital diplomacy). Według Riordana o dyplomacji cyfrowej (digital) należy mówić w kontekście korzystania z narzędzi cyfrowych w dyplomacji. Pod hasłem „narzędzia cyfrowe” rozumieć należy nie tylko media społecznościowe, ale również aplikacje analityczne, marketing automation narzędzia do analizy ruchu na stronie internetowej (np. stronie ambasady, konsulatu czy dowolnego projektu prowadzonego przez placówkę dyplomatyczną), big data ${ }^{1}$, data mining ${ }^{2}$, a także platformy cyfrowe, generujące scenariusze, symulacje konfliktów i grywalizację - wykorzystywaną szeroko np. w armii.

Poniekąd w opozycji do dyplomacji cyfrowej Riordan przedstawia dyplomację cybernetyczną (cyber). Autorski pomysł podziału Riordana budzi wiele kontrowersji, jednak dzięki wykorzystaniu doświadczenia dyplomatycznego bardzo dobrze porządkuje omawiane kwestie wykorzystania technologii informacyjno-komunikacyjnych przez dyplomatów. O dyplomacji cybernetycznej mówimy wtedy, gdy mowa jest o posługiwaniu się narzędziami dyplomatycznymi i dyplomatycznym nastawieniu do rozwiązania problemów pojawiających się w cyberprzestrzeni. Tu funkcję narzędzia pełni dyplomacja i jej przymioty - inaczej niż w dyplomacji cyfrowej.

Cyberdyplomacja ma za zadanie rozwiązać cyberzagrożenia, które powszechnie uważane są za ekwiwalent broni nuklearnej. Groźba wojny cybernetycznej wynika w dużej mierze z bezprawia panującego w cyberprzestrzeni (Riordan 2019).

Trzeci obszar, po digital i cyber, w którym technologia zdominowała dyplomację, przejawia się w postępującej współpracy rządów poszczególnych krajów z firmami technologicznymi. Relacje quasi-dyplomatyczne nawiązywane są na nieznanym dotąd poziomie. Naturalnie pojawiają się tu również elementy dyplomacji cyfrowej i cybernetycznej.

\footnotetext{
${ }^{1}$ Big data to najprościej „integracja co najmniej dwóch zbiorów danych celem ich porównania i wykazania zależności, bądź jej braku" (Gerschmann 2014). Więcej informacji na ten temat znaleźć można w specjalistycznych serwisach.

${ }^{2}$ Data mining to „p proces analityczny, przeznaczony do badania dużych zasobów danych [...] w poszukiwaniu regularnych wzorców oraz systematycznych współzależności pomiędzy zmiennymi, a następnie do oceny wyników poprzez zastosowanie wykrytych wzorców do nowych podzbiorów danych. Finalnym celem data mining jest najczęściej przewidywanie (zachowań klientów, wielkości sprzedaży, prawdopodobieństwa utraty klienta itp." (Electronic Statistics Textbook 2011).
} 
Kontakt rządu z przemysłem technologicznym ma na celu stworzenie konstruktywnego dialogu pomiędzy potęgami technologicznymi a poszczególnymi krajami. Pod pojęciem „konstruktywny dialog" kryje się ochrona własnych interesów przez obie strony. W przypadku krajów celem nadrzędnym zawsze jest bezpieczeństwo narodowe. Takie podejście wynika z potęgi firm, które niekiedy są silniejsze ekonomiczne, bardziej władne i decyzyjne niż poszczególne państwa (Horejsova, Ittelson, Kurbalija 2018).

\section{Dyplomatyczny lad w cyberprzestrzeni}

Mimo że komunikacja sensu stricto nie jest jedyną formą wykorzystania nowych technologii w dyplomacji, warto mimo wszystko dokładniej zbadać tę przestrzeń. Do digital diplomacy można zaliczyć takie odmiany dyplomacji, jak: dyplomacja wirtualna, e-diplomacy, twitterowa, facebookowa czy instagramowa. Jednym z pierwszych dyplomatów, który w 2007 roku rozpoczął intensywnie komunikować się ze społeczeństwem za pośrednictwem Twittera i zainaugurował nową erę dyplomacji, był Barack Obama, kiedy to piastował jeszcze urząd gubernatora stanu Illinois (Adler-Nissen 2018).

Z czasem przedstawiciele misji dyplomatycznych i politycy coraz częściej sięgali po tę formę komunikacji. Jedni, ponieważ docenili ten sposób kontaktu, inni - z obowiązku.

Autorem jednego z pierwszych polskich tweetów, który przeszedł do historii, był ówczesny Minister Spraw Zagranicznych Radosław Sikorski, który w 2014 roku ujawnił na Twitterze szczegóły negocjacji pokojowych toczących się za zamkniętymi drzwiami: „We are about to sign. Good compromise for Ukraine. Gives peace a chance. Opens the way to reform and to Europe. Poland and EU support it" (Sikorski 2014). Sikorski szybko uznany został za bohatera, który uratował pokój w Europie. Wkrótce jednak narracja diametralnie zmieniła swój kierunek, a ówczesny Minister Spraw Zagranicznych był ostro krytykowany za ujawnienie informacji przed ich ostatecznym zatwierdzeniem (Adler-Nissen 2018).

Internet stał się tubą, dzięki której wszystkie grupy społeczne, zawodowe, partie polityczne, rządy mogły jaśniej, dobitniej, głośniej, dalej, szybciej dzielić się informacjami, komunikować swoje potrzeby, poglądy czy zbierać opinie społeczeństwa na dany temat.

Naturalnym rezultatem były zmiany przyzwyczajeń dyplomatów, którzy dzieląc się wynikami negocjacji, sukcesami w rozmowach, osiągnięciami kraju czy przemyśleniami w mediach społecznościowych, stali się bardziej dostępni, a co za tym idzie bardziej „zwyczajni”.

Niestety, wraz z rosnącą dostępnością zaczął unaoczniać się problem zaufania do publikowanych treści. O zatarciu granicy pomiędzy nadawcą a odbiorcą komunikatu, odejściem od modelu zinstytucjonalizowanego nadawcy, a co za tym idzie - manipulowaniu przekazem medialnym mówi między innymi Siva Vaidhyanathan (Łozowska 2018: 105). Niezbędne jest zatem zwiększenie czujności, szczególnie gdy przejęcia kont są obecnie tak powszechne. 
Większość dyplomatów tweetuje samodzielnie. Komunikacja za pomocą tego narzędzia stała się nową normalnością.

Dyplomacja cyfrowa dość szybko została zaadaptowana przez rządy - z początku krajów bardziej rozwiniętych technologicznie, a obecnie już większości państw. Korzystanie z cyfrowej technologii stało się łatwe i opłacalne nawet dla stosunkowo małych i niezbyt zamożnych krajów. Kraje bałtyckie inwestują w komunikację cyfrową poprzez media społecznościowe, strony www, jak również komunikatory. Podobnie kraje afrykańskie coraz chętniej dołączają do platform cyfrowych, by ponownie nawiązać kontakt z diasporą, ułatwić wzrost ekonomiczny i wzmocnić bilateralne relacje (Manor 2018).

Taka forma dyplomacji stosowana jest również przez Polskie Ministerstwo Spraw Zagranicznych. Na swojej stronie internetowej MSZ prezentuje „Polską dyplomację cyfrową", gdzie znaleźć można wykaz kont społecznościowych polskich placówek dyplomatycznych, kont społecznościowych MSZ, a także adresy kont społecznościowych polskich placówek dyplomatycznych za granicą.

W odpowiedzi na rosnące znaczenie technologii w obszarze dyplomatycznym popularny stał się termin real-time diplomacy, który ukuł Philip Seib. Określenie to odnosi się bezpośrednio do przyśpieszenia praktyki dyplomatycznej i reagowania na bieżąco (w czasie rzeczywistym) na wszelkie istotne kwestie (Manor 2017).

Media społecznościowe to również doskonałe narzędzie do szybkiego wyrażania stanowiska kraju w danej sprawie. Obecnie, przy niezmiernie krótkiej żywotności newsów, fundamentalna stała się prędkość ich rozprzestrzeniania. Wzorcowym przykładem real-time diplomacy jest reakcja Czechów na zarzuty rosyjskich władz w sprawie użycia na terenie Wielkiej Brytanii środka chemicznego. W reakcji na sugestię rzeczniczki rosyjskiego MSZ Marii Zacharowej, która podała do publicznej wiadomości, że „najbardziej prawdopodobnym miejscem pochodzenia związku, którego użyto w brytyjskim Salisbury w zamachu na Skripala, jest sama Wielka Brytania lub Republika Czeska, Słowacja, Szwecja, a być może USA" (TVN24 2018), czescy ministrowie nazwali te insynuacje „absurdem”3 ${ }^{3}$, przedstawiając swoje stanowisko w mediach społecznościowych: „Protestujemy przeciwko oświadczeniom o pochodzeniu (tej toksyny), których w żaden sposób nie można udowodnić" - napisał na Twitterze szef czeskiego MSZ Martin Stropnicky. „To standardowy sposób manipulowania informacją w przestrzeni publicznej, kiedy przedstawia się wysoce spekulatywny komunikat, którego nie sposób udowodnić" - dodał minister Stropnicky w nawiązaniu do słów Zacharowej" (TVN24 2018).

\footnotetext{
34 maja 2018 roku czeski resort obrony poinformował, że zgodnie z ogłoszonymi dzień wcześniej przez Prezydenta Czech Miłosza Zemana informacjami na terenie Czech była produkowana w niewielkich ilościach substancja typu nowiczok , , w celu szkolenia wojska w zakresie obrony przeciwchemicznej”. Jednak „środek A-234 użyty podczas ataku na Skripala różni się od A-230 testowanego w laboratorium w Brnie". Szczegółową informację na ten temat podaje portal TVN24 (TVN24 2018).
} 
Media społecznościowe z pewnością powinny być używane w komunikacji dyplomatycznej na poziomie międzynarodowym. Ich rola nie podlega dyskusji. Można przytoczyć wiele przykładów demonstrujących próby podejmowane przez dyplomatów w celu natychmiastowego zajęcia stanowiska w danej sprawie. Dyskusyjny jest natomiast sposób i treść przekazywanych wiadomości. Swoistą rewolucję w postrzeganiu dyplomacji cyfrowej, ocierającą się wręcz o pastisz, przeprowadził Prezydent Stanów Zjednoczonych Donald Trump, który w sposób dotąd nieznany wśród dyplomatów zaczął komunikować się z wyborcami, ale i ze światem, za pośrednictwem Twittera.

Przyczynkiem do dyskusji o rosnącym znaczeniu komunikatorów internetowych może być również sytuacja, w której Prezydent Stanów Zjednoczonych ogłasza zmiany kadrowe na najwyższym szczeblu państwowym na swoim profilu na Twitterze. Wspomniany przypadek dotyczy odwołania ze stanowiska Sekretarza Stanu Stanów Zjednoczonych, Rexa Tillersona i powołania na to miejsce byłego już dyrektora CIA Mike'a Pompeo.

Fakt, że obywatele Stanów Zjednoczonych, a także światowa opinia publiczna, wraz $z$ samym zainteresowanym Rexem Tillersonem, dowiadują się o zmianie na jednym z najwyższych stanowisk w strukturach rządu Stanów Zjednoczonych za pośrednictwem portalu społecznościowego, demonstruje wzmocnienie się tego źródła przekazu i zwiększenie jego wartości dla polityków i dyplomatów.

Nie podlega dyskusji kwestia, że Donald Trump jak żaden inny polityk używa Twittera w sposób niespotykany dotąd w świecie dyplomacji, a tym samym w prawie dyplomatycznym - oprócz tego, że ogłasza odwołania i awanse, to wypowiada swoje opinie na różne tematy, zapominając o niezbędnej w takich przypadkach wstrzemięźliwości w wyrażaniu opinii; a nawet grozi głowom innych państw, jak miało to miejsce w przypadku Marszałka i Przewodniczącego Partii Pracy Korei Północnej - Kim Dzong Una. Prezydent zbyt często korzystający z Twittera - tak pisze o Donaldzie Trumpie Tom Engelhardt, amerykański komentator polityczny, w artykule zatytułowanym Najbardziej niebezpieczny człowiek na Ziemi (Engelhardt 2018).

Włączenie nowych technologii do prowadzenia działań dyplomatycznych ma również inne wymiary. Dyplomacje publiczne Izraela, Stanów Zjednoczonych i Szwecji jako pierwsze zaadaptowały do swoich działań technologię cyfrową - przede wszystkim do kontaktu ze społeczeństwem. Praktyki te zakwalifikować można jako dyplomację wirtualną czy e-dyplomację.

W 2007 roku Szwecja utworzyła ambasadę w wirtualnym świecie Second Life. W 2011 roku powstał projekt Wirtualnej Ambasady Departamentu Stanu w Iranie, która miała na celu podtrzymywanie relacji pomiędzy Amerykanami a Irańczykami, mimo braku formalnych stosunków bilateralnych (Manor 2018). Wirtualne relacje nawiązały również w 2014 roku Iran i Izrael - jednak w tym przypadku była to wojna o cement w mediach społecznościowych, pełna wzajemnych oskarżeń (Manor 2014).

Dyplomacja cyfrowa to także korzystanie z aplikacji do analizy informacji przez Ministerstwo Spraw Zagranicznych czy przedstawicieli placówek dyplomatycznych. 
Marketing automation, korzystanie z danych, w celu zidentyfikowania odbiorców i prognozowania ich zachowań, jak również najprostsze narzędzia oferowane przez Google także powinny zostać włączone w działalność informacyjną dyplomacji.

Narzędzia z portfela ICT wykorzystywane są również podczas komunikacji z potencjalnymi wyborcami (Eckardt 2014: 12). Coraz częściej jednak działania tego typu wywołują kontrowersje. Wątpliwości budzi m.in. sposób pozyskiwania danych. Podczas wyborów prezydenckich w Stanach Zjednoczonych sztab wyborczy milionera Donalda Trumpa, ubiegającego się o prezydenturę, wykorzystał infrastrukturę serwisu Facebook do rozpowszechniania populistycznych, a często fałszywych czy wręcz obraźliwych informacji. Skandal wybuchł, gdy w mediach pojawiły się fragmenty rozmowy z byłym pracownikiem firmy Cambridge Analytica, dotyczącej nieprawidłowości w sposobie pozyskiwania, a następnie wykorzystywania do profilowania komunikatów wyborczych Trumpa danych milionów użytkowników tego medium (Jakubowiak 2019).

Doskonałą metodą treningu przewidywania pewnych kroków w środowisku kontrolowanym jest wspomniana wcześniej grywalizacja, obecnie szeroko wykorzystywana na potrzeby wojska, ale też mająca ogromny potencjał w działaniach dyplomatycznych prowadzonych na arenie międzynarodowej.

Kontynuując próbę uporządkowania terminologii, nie można zapominać o niezwykle ważnym aspekcie, jakim jest zapewnienie bezpieczeństwa w cyberprzestrzeni. Według Strategii Bezpieczeństwa Rzeczypospolitej Polskiej na lata 2017-2022 cyberprzestrzeń rozumiana jest jako „przestrzeń przetwarzania i wymiany informacji tworzona przez systemy teleinformatyczne wraz z powiązaniami pomiędzy nimi oraz relacjami z użytkownikami" ${ }^{4}$.

Cyberbezpieczeństwo (cybersecurity) to dziedzina zgłębiana przez fachowców na uczelniach technicznych i wojskowych. Jednak podobnie jak Shaun Riordan uważam, że nie można pozostawić cyberprzestrzeni w rękach techników (Riordan 2019). Ten niezwykle wrażliwy obszar oprócz znajomości technicznych wymaga przede wszystkim odpowiednio skomponowanych cech i umiejętności, którymi dysponują zawodowi dyplomaci, takich jak profesjonalne prowadzenie negocjacji, umiejętność myślenia strategicznego i przewidywania konsekwencji czy szeroka perspektywa postrzegania. O multidyscyplinarnym podejściu i współpracy na różnych poziomach mówi również Estońska Ambassador at Large ds. Cyberbezpieczeństwa Heli Tiirmaa-Klaar (Maack 2019).

Nad uporządkowaniem zagadnień związanych z przestrzenią cybernetyczną, a także nad nowymi zapisami prawa międzynarodowego regulującymi te wrażliwe kwestie od lat pracują naukowcy, informatycy i prawnicy z całego świata, jednak nadal brak jest jednoznacznej odpowiedzi na pytanie, jak definiować np. atak w cyberprzestrzeni - co w przypadku innych form agresji nie stanowi wątpliwości (Maack 2019). Jednak

${ }^{4}$ Różne pojęcia cyberprzestrzeni i cyberbezpieczeństwa przedstawia w swojej pracy Zarys definicji cyberprzestrzeni Janusz Wasilewski (2013). 
ogromny krok w stronę kodyfikacji nielegalnych działań prowadzonych w cyberprzestrzeni postawiony został 17 maja 2019 roku. Rada Unii Europejskiej ustanowiła nowy system sankcji, które mają powstrzymać ataki cybernetyczne, stanowiące zagrożenie dla państw członkowskich (Cyber-attacks...2019).

\section{Nowe trendy w dyplomacji}

Technologia w dyplomacji zaczęła uwidaczniać się na różnych płaszczyznach. Tłumaczy to szeroką nomenklaturę, która stosowana jest w kontekście innowacyjnych form dyplomacji, ale także nowych funkcji piastowanych przez dyplomatów.

Konsulaty zaczęły przejmować rolę agencji promocji inwestycji lub też ściśle z nimi współpracować. Coraz więcej placówek konsularnych tworzy stanowiska dla specjalistów do spraw technologii: attache ds. ekonomii, attache ds. inwestycji, attache ds. innowacji - jak ma to miejsce m.in. w Konsulacie Generalnym Holandii w San Francisco (Horejsova, Ittelson, Kurbalija 2018). Komunikacji z diasporą danego kraju czy wsparciu w realizacji czynności konsularnych towarzyszy angażowanie obywateli danego kraju w relacje z technologią. Często też funkcję reprezentanta cyfrowej dyplomacji przejmuje konsul honorowy. Takie rozwiązanie przyjęły kraje mniej zamożne (Horejsova, Ittelson, Kurbalija 2018). Coraz częściej pojawiają się również dedykowani ministrowie czy ambasadorzy at-large, specjalizujący się w kwestiach cyberbezpieczeństwa, sztucznej inteligencji (Al), Internetu rzeczy (IoT) czy blokchainu. Działania te są naturalnym następstwem rozwoju świadomości wyzwań i zagrożeń występujących w cyberprzestrzeni.

W odpowiedzi na dominującą rolę technologii praktycznie w każdej gałęzi gospodarki Dania - jeden z najbardziej rozwiniętych krajów na świecie -jako pierwsza stworzyła stanowisko tech ambasadora. Pierwszym na świecie tech ambasadorem został w 2017 roku doświadczony dyplomata, który urząd ambasadora piastował uprzednio kilkakrotnie - Casper Klynge. Znaczenie tego neologizmu, stworzonego z potrzeby nadążania za rozwijającym się światem, najlepiej wyjaśnia Dania na stronie internetowej biura duńskiego tech ambasadora: „Techplomacy - uznanie dla kluczowej roli, jaką technologia i digitalizacja odgrywają i będą odgrywać w przyszłości zarówno dla poszczególnych osób, jak i społeczeństwa. To również uznanie politycznego i globalnego wpływu, jaki przemysł technologiczny ma w XXI wieku. Technologia będzie odgrywać rolę w rozwiązywaniu najpoważniejszych globalnych wyzwań i doprowadzi do pozytywnej zmiany z ogromnym potencjałem dla ludzi z całego świata" (Office of Denmark's Tech Ambassador).

Minister Spraw Zagranicznych Danii Anders Samuelsen w rozmowie z „Politiken”, duńskim dziennikiem, wyjaśnia, że duże firmy (głównie technologicznie) wpływają na Danię równie silnie jak całe państwa. Tego typu firmy stają się nowym typem państwa i należy się z tym zmierzyć (Gramer 2018). 
Wśród krajów, które równie szybko zauważyły potrzebę współpracy na nowym poziomie, jest Francja. Mianowany przez Radę Ministrów, zatwierdzony przez prezydenta Francji Emmanuela Macrona, David Martinon został ambasadorem Francji ds. stosunków cyfrowych w 2017 roku (France Diplomatie). Obecnie Martinon jest odpowiedzialny za francuską placówkę dyplomatyczną w Kabulu, natomiast kolejnym przedstawicielem Francji w stosunkach cyfrowych został Henri Verdier. Do obowiązków ambasadora cyfrowego należą m.in.: międzynarodowe negocjacje w temacie cyberbezpieczeństwa, kierowanie sieciami internetowymi, ochrona własności intelektualnej w Internecie, a także wsparcie dla operacji eksportowych firm cyfrowych. Natomiast jednym z kluczowych zadań jest budowanie i pielęgnowanie dialogu z głównymi amerykańskimi platformami cyfrowymi w walce z korzystaniem z Internetu dla celów terrorystycznych (Digital affairs... 2017). Francuzi wyjaśniają, że zadanie jest realizowane zgodnie z wytycznymi przyjętymi przez grupę G7 na szczycie w Taorminie na Sycylii w czerwcu 2017 roku, jak również zgodnie z francusko-brytyjskim planem działania z lipca 2017 roku oraz wnioskami do tych programów, złożonymi przez francuskiego prezydenta oraz premierów Wielkiej Brytanii i Włoch podczas spotkania wysokiego szczebla na temat zapobiegania terroryzmowi w Internecie, podczas zgromadzenia ogólnego ONZ w Nowym Jorku (Sandre 2017).

Reprezentacja dyplomatyczna w postaci specjalistów ds. cyfrowych okazała się niezwykle pożądana, tym bardziej, że obecnie jest to jedna z ważniejszych dziedzin geopolityki (Maack 2019). Niektóre rządy zdały sobie sprawę (a pozostałe wkrótce pójdą w ich ślady), że przedstawiciel, który zadba o sprawy związane z kwestiami technologicznymi na arenie międzynarodowej, jest obecnie niezbędny.

Stałe przedstawicielstwa dyplomatyczne mogą okazać się w tej materii niewystarczające. Stąd pomysł, aby to dedykowany wysłannik dbał o pozycję swojego państwa w cyberprzestrzeni, prowadził rozmowy z potęgami technologicznymi o zapewnieniu bezpieczeństwa i zwalczaniu cyberterroryzmu, nadzorował walkę z dezinformacją, czy wspierał promocję rodzimych start-upów za granicą.

Dla wielu dyplomatów kwestie te niestety nadal pozostają niejasne, a techniczny żargon może zniechęcić ich do współpracy na tym polu. Heli Tiirmaa-Klaar uważa, że to właśnie wyspecjalizowani dyplomaci, tacy jak ona, powinni pełnić rolę tłumaczy i znaleźć sposób na podjęcie niezbędnych działań w celu poprawy bezpieczeństwa. Ten nowy gatunek urzędników państwowych również musi odejść od tradycyjnego myślenia, aby stawić czoła zagrożeniom, przed którymi stoi obecnie świat (Maack 2019). Odejście od tradycyjnego myślenia oznacza wyjście poza schematy w postrzeganiu bezpieczeństwa, a przede wszystkim zdefiniowanie na nowo roli dyplomaty, którego umiejętności i wiedzę można wykorzystać o wiele szerzej niż dotychczas.

Praktyki te zaowocowały pierwszym międzynarodowym spotkaniem 22 cyber i tech ambasadorów oraz specjalnych wysłanników rządów z przemysłem technologicznym, które odbyło się w kwietniu 2019 roku w Dolinie Krzemowej (Klynge 2019). W spotkaniu uczestniczyli przedstawiciele m.in. takich firm, jak: Microsoft, Apple, Google, Sisco, 
Facebook czy FireEye. Polskę w Dolinie Krzemowej reprezentował Marek Szczygieł, dyplomata, specjalista ds. cyberbezpieczeństwa.

Dyskusje skupiły się wokół dwóch wiodących kwestii: jak złagodzić rosnące zagrożenie ze strony cyberprzestępców; jak najlepiej przygotować się na udział firm technologicznych w polityce zagranicznej i ich wpływ na bezpieczeństwo (Klynge 2019). Spotkanie uwypukliło potrzebę dialogu pomiędzy rządami a przemysłem technologicznym.

\section{Zakończenie}

Jak widać, technologia i dyplomacja wchodzą w coraz większą korelację, a ich współistnienie zaczyna nabierać mocy prawnej. Rola wielonarodowych korporacji technologicznych jako uczestników stosunków międzynarodowych staje się coraz wyraźniejsza. Ewolucja polityki zagranicznej w sieciowe środowisko doprowadziła do przełomu zarówno państwa, jak i sektor niepaństwowy mogą ze sobą współpracować na jednym poziomie. Jednak, jak słusznie zauważa prof. Corneliu Bjola z Uniwersytetu Oxford, aby to co się rozpoczęło z takim impetem mogło dalej funkcjonować prawidłowo, również firmy muszą rozwinąć swoje umiejętności i narzędzia dyplomatyczne. Bjola żywi przekonanie, że już wkrótce największe firmy technologicznie zinstytucjonalizują również rolę swoich cyfrowych wysłanników (Sandre 2017).

Firmy nie posiadają co prawda cech podmiotowości prawnomiędzynarodowej, jednak jeżeli droga, którą wspólnie podążają dyplomacja i giganty technologiczne, nie zmieni kierunku, być może to tylko kwestia czasu, gdy najpotężniejszym firmom przyznana zostanie zdolność do czynności prawnych w stosunkach międzynarodowych (Bierzanek, Symonides 2004: 118).

Być może to jednak zbyt daleko idące przypuszczenia. Dynamika zmian utrudnia prognozowanie. Pewny natomiast jest fakt, że jest to niezwykle obszerne i interesujące zagadnienie, które w niespotykanym dotąd tempie ewoluuje. Kwestie aktualne dziś, jutro mogą odejść w zapomnienie, dlatego tak ważna jest nieustanna obserwacja kierunku, w którym zmierza dyplomacja, wspierana przez nowoczesną technologię, a aktualnie również technologia przy wsparciu dyplomacji.

\section{Bibliografia}

Adler-Nissen R., 2018, TEDx Kopenhaga, www.youtube.com/watch?v=2jouximzU1k\&t=308s [dostęp: 20.05.2019].

Bierzanek R., Symonides J., 2004, Prawo międzynarodowe publiczne, Warszawa.

Cyber-attacks: Council is now able to impose sanctions, Council of the European Union. 2019, https:// www.consilium.europa.eu/en/press/press-releases/2019/05/17/cyber-attacks-council-is-now-able-to-impose-sanctions/ [dostęp: 08.09.2019]. 
Digital affairs - appointment of an ambasador, France Diplomatie, 2017, https://www.diplomatie. gouv.fr/en/french-foreign-policy/digital-diplomacy/events/article/digital-affairs-appointment-of-an-ambassador-22-11-17 [dostęp: 23.05.2019].

Działoszyńska M., 2018, Łowienie wyborców na Facebooku, 'Gazeta Wyborcza”, nr 66.9280, 20 marca. Eckardt M., 2014, The impact of ICT on Policies, Politics and Polities - An Evolutionary Economics Approach to Infomation and Communication Technologies (ICT), Andrassy Working Paper Series No. 32.

Engelhardt T., 2018, Najbardziej niebezpieczny człowiek na ziemi, Le Monde diplomatique, edycja polska, $\operatorname{nr} 2$ (144).

Internetowy Podręcznik Statystyki, www.statsoft.pl/textbook/stathome_stat.html?https\%3A\%2F\%2 Fwww.statsoft.pl\%2Ftextbook\%2Fstdatmin.html [dostęp: 27.05.2019].

Gerschmann P., 2014, Spiders Web, www.spidersweb.pl/2014/05/big-data-2.html [dostęp: 20.05.2019]. Gramer R., Denmark creates the World's First Ever Digital Ambassador, www.foreignpolicy.com [dostęp: 13.08.2018].

Horejsova T., Ittelson P., Kurbalija J., 2018, The rise of techplomacy in the bay area, www.diplomacy. edu [dostęp 05.12.2018].

Jakubowiak M., 2019, Niekompatybilne technologie, http://www.miesiecznik.znak.com.pl/ niekompatybilne-technologie/ [dostęp: 08.09.2019].

Klynge C., 2019, Linkedln, www.linkedin.com/feed/update/urn:li:activity:6520791293940023296/ [dostęp: 20.05.2019]

Kosienkowski M., 2014, Dyplomacja cyfrowa po rosyjsku [w:] M. Kosienkowski, B. Piskorska (red.), Dyplomacja cyfrowa jako instrument polityki zagranicznej państwa XXI wieku, Lublin.

Kurbalija J., 2016, An Introduction to Internet Governance 7th edition, www.issuu.com/diplo/docs/ anintroductiontoig_7th_edition [dostęp: 24.05.2019].

Łozowska H., 2018, Algorytmy wobec demokracji, „Media Kultura Komunikacja Społeczna”, t. 14, nr 4. Maack M. M., 2019, What the hell is a 'cyber diplomat'?, www.thenextweb.com/eu/2019/05/24/what-the-hell-is-a-cyber diplomat/amp/?_twitter_impression=true [dostęp: 31.05.2019].

Manor I., 2014, Iran and Israel establish Virtual Relations, www.digdipblog.com/2014/03/15/iran-and-israel-establish-virtual-relations/ [dostęp: 04.08.2018].

Manor I., 2017, Can social media reduce the risk of war?, www.uscpublicdiplomacy.org/blog/can-social-media-reduce-risk-war [dostęp: 23.07.2018].

Manor I., 2018, An optimistic research agenda for digital public diplomacy, www.uscpublicdiplomacy. org/blog/optimistic-research-agenda-digital-public-diplomacy [dostęp: 12.12.2019].

Oficjalna strona internetowa Ministerstwa Spraw Zagranicznych RP, www.msz.gov.pl/pl/aktualnosci/polska_dyplomacja_cyfrowa/ [dostęp: 15.08.2018].

Portal TVN24, 2018, Rosja sugeruje, że środek użyty w ataku na Skripala pochodzi z Czech, www.tvn24. $\mathrm{pl} / \mathrm{msz}$-rosji-srodek-uzyty-w-ataku-na-skripala-moze-pochodzic-z-czech,823087,s.html [dostęp: 20.05.2018].

Portal TVN24, 2018, Prezydent Czech: był u nas produkowany nowiczok, www.tvn24.pl/czechy-produkowaly-substancje-typu-nowiczok,834504,s.html [dostęp: 20.05.2018].

Riordan S., 2016, Cyber Diplomacy vs. Digital Diplomacy: A terminological distinction, www.uscpublicdiplomacy.org/blog/cyber-diplomacy-vs-digital-diplomacy-terminological-distinction [dostęp: 03.06.2018].

Riordan S., 2019, 5G: The Real Reason Behind US Attacks On Huawei, www.thecorner.eu/world-economy/5g-the-real-reason-behind-us-attacks-on-huawei/78010/ [dostęp: 20.05.2019]. 
Sandre A., 2017, Welcome to the era of tech diplomacy, www.medium.com/digital-diplomacy/ welcome-to-the-era of-tech-diplomacy-2e174446d25 [dostęp: 09.03.2018]

Seweryn R., 2017, Technologie informacyjne i komunikacyjne - wprowadzenie w problematykę [w:] Technologie informacyjne i komunikacyjne na rynku turystycznym, Warszawa.

Sikorski R., 2014, Twitter, www.twitter.com/sikorskiradek/status/436857323177668608 [dostęp: 23.09.2018].

Strategia Cyberbezpieczeństwa Rzeczypospolitej Polskiej na lata 2017-2022, https://www.gov.pl/ documents/31305/0/strategia_cyberbezpieczenstwa_rzeczypospolitej_polskiej_na_lata_2017__2022.pdf/f249b627-4050-a6f4-5cd3-351aa025be09 [dostęp: 08.09.2019].

Surmacz B., 2015, Ewolucja współczesnej dyplomacji. Aktorzy. Struktury. Funkcje, Lublin.

The official website of the Office of Denmark's Tech Ambassador, www.techamb.um.dk/en/ techplomacy/.

Wasilewski J., 2013, Zarys definicji cyberprzestrzeni, „Przegląd Bezpieczeństwa Wewnętrznego”, nr 9.

\section{Biogram}

Król Paulina - doktorantka na wydziale Prawa i Administracji na Uniwersytecie Gdańskim. Absolwentka Uniwersytetu Gdańskiego na kierunku filologia rosyjska. Ukończyła studia podyplomowe w Collegium Civitas w Warszawie na kierunku dyplomacja kulturalna w 2012. W tym samym roku odbyła staż w Ambasadzie RP w Londynie. Dwa lata później otrzymała dyplom poświadczający ukończenie studiów podyplomowych z zakresu służby zagranicznej w Szkole Głównej Handlowej w Warszawie. Ukończyła Kurs Doskonalący Protokołu Dyplomatycznego, organizowany przez Wojskowe Centrum Edukacji Obywatelskiej. Badaczka źródeł protokołu dyplomatycznego. Od wielu lat pracownik administracji państwowej. Prowadzi bloga o gafach dyplomatycznych i międzynarodowych nieporozumieniach z tego wynikających. Zajmuje się szeroko pojętą dyplomacją - od jej historii po nowoczesne formy. W 2017 opublikowała artykuł zatytułowany „Dyplomacja oparta na religii stosunki dyplomatyczne Chin z Watykanem wczoraj i dziś". Doradza w temacie etykiety i protokołu dyplomatycznego. Okazjonalnie prowadzi szkolenia z savoir-vivre'u. 